\title{
Mining Impact on Livelihoods of Farmers of Asutifi North District, Ghana
}

\author{
Felix Agariga \\ University of Energy and Natural Resources (UENR), Department of Forest Science \\ P.O. Box 214, Sunyani, Ghana \\ E-mail: windaagariga@yahoo.com \\ Simon Abugre \\ University of Energy and Natural Resources (UENR), Department of Forest science \\ P. O. Box 214. Sunyani, Ghana \\ E-mail: Simon.abugre@uenr.edu.gh
}

Ebenezer K. Siabi

Earth Observation Research and Innovation Center

P. O. Box 214, UENR, Sunyani, Ghana

E-mail: siabikebenezer@gmail.com

Mark Appiah (Corresponding author)

CSIR College of Science and Technology (CCST)

P. O. Box M32, Accra, Ghana

E-mail: anmark.appiah@gmail.com

Received: July 20, 2021 Accepted: August 30, 2021 Published: October 2, 2021

doi:10.5296/emsd.v10i4.19066 URL: https://doi.org/10.5296/emsd.v10i4.19066

\section{Abstract}

Local communities in Ghana are heavily reliant on agriculture for their livelihoods. However, 
they are increasingly shifting from engaging in agriculture to mining. This study was undertaken to assess the impact of mining (both small and large scale) on the livelihoods of community members of Kenyasi, Asutifi North District in Ghana. Data were collected from 201 farming households who were selected randomly and interviewed for a variety of information. The questionnaire responses received from the respondents were classified into items and each item's responses were tallied. The results of the studies show that the farmers' livelihood systems were affected by the mining operations occurring around their communities. Water pollution, displacement of farmers from their lands, degradation of agricultural lands, and an increase in social vices and higher dropout rates of students from schools are some of the reported consequences of the mining activities. The pollution of the water resources poses a serious threat to the health and livelihood systems of these farmers as they depend on the water resources for agriculture and domestic use. In this study, we project that there could be increased grievances over scarce land resource and food insecurity that could lead to conflicts in the mining areas. The lack of land resources could have a tremendous effect on the social, economic, and political climate of a country and must be considered and addressed as some of the most immediate threats to Ghana's national security.

Keywords: Environmental conflict, Agricultural land degradation, Displacement, Food insecurity, Mining, Ghana

\section{Introduction}

Ghana, like many other African countries, has an economy that is mainly agrarian with agriculture accounting for a substantial share of rural production and employment. In Ghana, agriculture is no longer the dominant livelihood activity in some rural communities. Mining has now become a significant land use practice among some local communities, providing employment opportunities and income to these communities' members. These two land uses, mining, and agriculture, have several social (Mancini and Sala, 2018), economic (Walser, 2002), and environmental (Mate, 1992; Yelpaala and Ali, 2005) benefits. But they also have repercussions at both the local and national levels. Mining and agriculture bring about direct and indirect employment opportunities for local communities' members (Kuntala et al., 2014; Boateng et al., 2014), Mining activities also generate foreign income and tax revenues for the government (Aryee, 2001). Mining, for instances, brings about increased business activities and infrastructure development to communities where they operate (Chuhan-Pole, et al. 2015). There have been cases where basic infrastructures such as schools, roads, and health facilities are developed by mining companies in rural areas as part of their social responsibility (Amponsah-Tawiah and Dartey-Baah, 2011). However, there are several negative aspects to mining that have been reported. The quality of air and water tend to be polluted in rural environments where mining operations are undertaken (Akabzaa and Darimani, 2001; Habashi, 1996). Also, mining can displace the rural community from their lands (Wilson, 2019; Hilson and Banchirigah, 2009, Prajna, 2009), causing the local people to lose both their homes and agricultural lands (Schueler, et al., 2011; Ayensu-Ntim et al., 2015), and their forest-based livelihoods (Akram-Lodhi and Kay 2009; Ivanova and Rolfe 2011; Obeng et al. 2019). In developing countries various forms of mineral extraction and mining (large-scale) operations have resulted in dislodgement of a remarkable number of 
residents in remote regions (Aubynn, 2003; Hilson and Banchirigah, 2009; Doso Jnr et al., 2015). In Ghana for instance, land-use changes have been reported in Tarkwa, Bogoso/Prestea, and Damang where a large number of gold mining concessions are recorded (Doso Jnr et al., 2015; Peprah, 2016). This includes loss of agriculture lands, displacement of individuals from their habitation, and changes in occupational preferences by individuals (Doso Jnr et al., 2015; Peprah, 2016). In the case of Tarkwa Nsuaem Municipality (formerly Wassa West District) alone, a study by Garvin et al., (2009) reveals that an estimated 70\% of agricultural land has been signed as mining concession lands to large-scale mining companies by the government (Ocansey, 2013). Thus, individuals lose their major livelihood source (farmlands and rangelands) when they become displaced. Displacements and the loss of agricultural land also discourages youth participation in agriculture (Nyame et al., 2009). Mining activities are undermining the livelihood structures of local communities in Ghana. While the impact of mining at the macro level is widely reported, mining impacts on livelihoods at the local level in Ghana, as in other developing countries, is largely neglected as a field of study (Arnold and Bird, 1999). In this study the objective was to highlight the impacts of local small and large scale mining activities on the livelihoods of communities at the periphery of mining activities in Kenyase, Asutifi North District. This information should contribute to policy and management recommendation to address the impacts of mining on local communities.

\subsection{The Concept of Livelihood}

Livelihood is defined in this study as "a means of gaining a living and comprises the capabilities, assets, and activities required for a means of living" (Prajna, 2009). Livelihood was defined by Ellis (1999) as that which comprises “.... the assets (natural, physical, human, social and financial capital), the activities, and the access to these that together determine the living gained by the individual or household". Livelihood is termed to be 'sustainable' when after stress and shocks, it is able to make quick recoveries and maintain its abilities and assets to provide the next generation with sustainable opportunities the short- and long-term (Chambers and Conway, 1992).

\subsection{Mining in Ghana}

Mining, which is the extraction of minerals and metals from the Earth has for decades created employment for people and provided many nations with wealth that has led to economic development in most of these countries (Chuhan-Pole et al., 2015). Despite these benefits, mining has been associated with many environmental problems. Such problems include pollution of water bodies as a result of the discharge of effluents into these water bodies. The effluents are known to contain toxic chemicals such as cyanide and other organic chemicals used in the processing of mineral ores. Another environmental problem associated with mining is the leaching of heavy metal oxides that contaminate the environment including surface and underground water resources. This not only poses a threat to human health but also poses a serious threat to aquatic and other life forms in the environment (Aryee et al., 2003). There are wars in many African countries that are endowed with these resources, destroying the social lives of their citizens. Despite all the challenges posed by large scale 


\section{Macrothink}

licensed mining, other challenges have arisen in most African countries including Ghana. Uncontrolled small-scale and illegal mining activities has been on the rise and significantly contributes to land use and land cover changes and environmental degradation (Agariga et al., 2021). Reports suggest that more people are engaging in this mining without the appropriate documentation from the regulatory bodies including the Minerals Commission of Ghana. In Ghana for instance, about 80,000 local people, including women, are currently involved in small-scale mining (legal and illegal) of gold (Aryee et al. 2003).

\section{Materials and Methods}

\subsection{Study Area}

The Asutifi North District is located between $6^{\circ} 40^{\prime \prime}$ and $7^{\circ} 15^{\prime \prime}$ North and Longitudes $2^{\circ} 15^{\prime \prime}$ and $2^{\circ} 45^{\prime}$ West (Figure1). It is one of the Nineteen (19) districts in the Bono Region. This district was chosen for the study because of the increasing rate of mining activities and deforestation, which is gradually transitioning the forest cover in the district to savannah woodlands. The climate is tropical in nature, with the mean temperature ranging between 26 and 30 degree Celsius. The district has an average yearly rainfall of 1,200 $\mathrm{mm}$. The natural vegetation of the site is the deciduous forest type with flora in this forest type ranging from shrubs and climbers to timber trees such as Ceiba pentadra, Tripolichiton scleroxylon, Milicia excelsa, Guthagrophrama sp. and Khaya ivorensis) (Hall and Swaine, 1981). The soil in the study is mostly fertile and well-drained ochresols (Hall and Swaine, 1981).

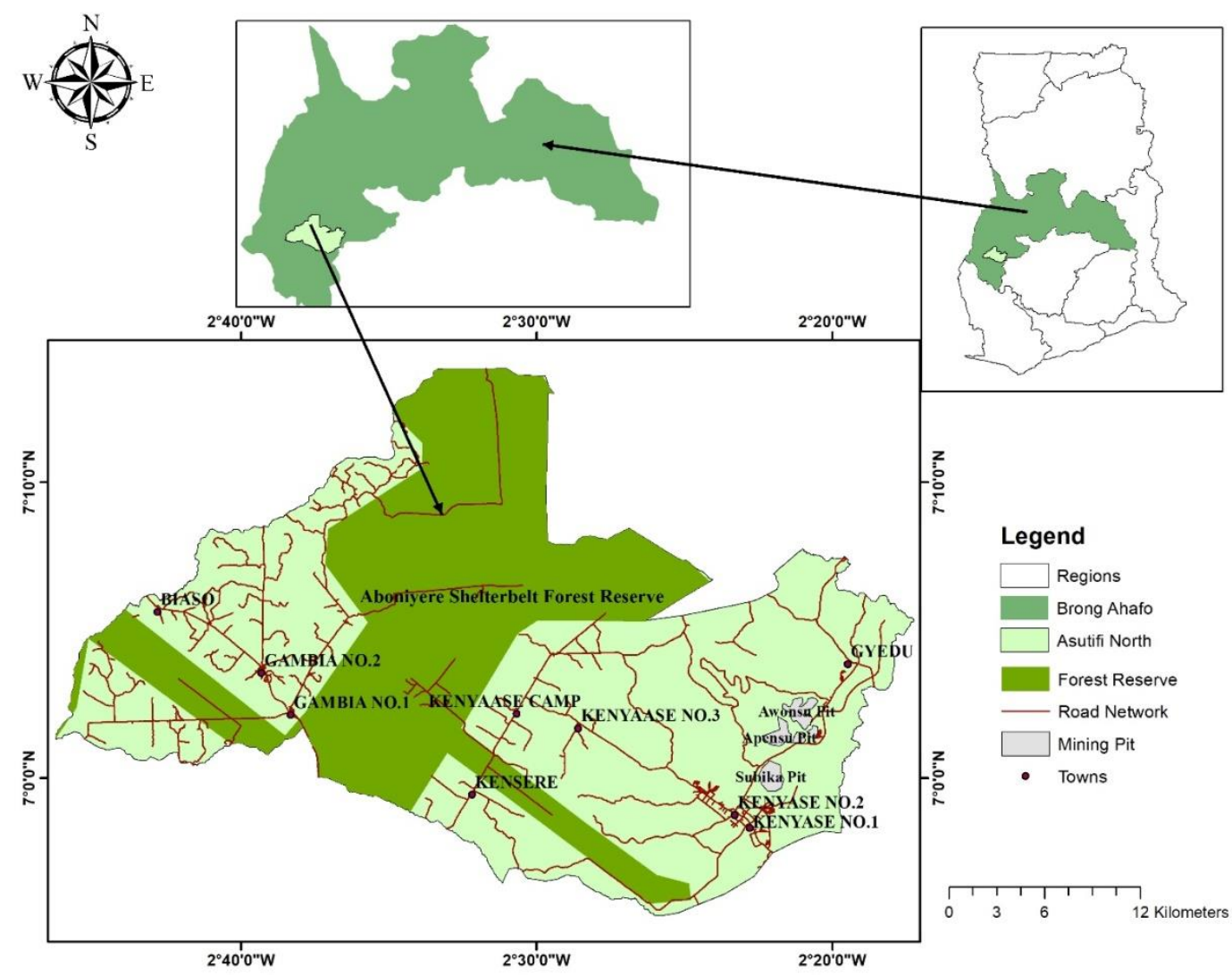

Figure 1. Map showing Ahafo region of Ghana with its districts including Asutifi 


\subsection{Socioeconomic Characteristics of Respondents}

A total of 101 and 100 respondents responded to the survey for Kenyase 1 and 2 respectively (Table 1). Males slightly outnumbered females, representing 52.7 percent of the total respondents. The household size of the majority of the respondents fell between 3-5 people per house. As to age, the majority of the respondents were 36 and above. This reveals that the majority of them were adults. The youth population, ranging from 18-25, was very low accounting for 2.5 percent of the total population of the respondents. Majority of the respondents (147) representing 73.1 percent were natives of both Kenyasi No1 and Kenyasi No2 communities. As to educational level of respondents, most of them had only a basic education with only 53 respondents representing 26.4 percent attaining tertiary education. For their occupation, most of the respondents were found to be full-time or part-time farmers. According to Agariga et al. (2021), almost 98 percent of the respondents were farmers with about 16 and above years of working experience (Table 1). Rural livelihoods vary across countries and regions. Households in mining communities usually tend to engage in diverse economic activities including mining, agriculture, and subsistent business.

Table 1. Demographic characteristics of respondents ( $\mathrm{N}=201)$ (Agariga et al. 2021)

\begin{tabular}{|c|c|c|c|}
\hline \multicolumn{2}{|l|}{ Variable } & Frequency of responses & Percent response \\
\hline \multirow{3}{*}{$\begin{array}{l}\text { Communities involved } \\
\text { in study }\end{array}$} & Kenyase 1 & 101 & 50.2 \\
\hline & Kenyase 2 & 100 & 49.8 \\
\hline & Total & 201 & 100.0 \\
\hline \multirow[t]{3}{*}{ Gender } & Male & 106 & 52.7 \\
\hline & Female & 95 & 47.3 \\
\hline & Total & 201 & 100.0 \\
\hline \multirow{5}{*}{$\begin{array}{l}\text { Number of individuals } \\
\text { in a household }\end{array}$} & $0-2$ & 29 & 14.5 \\
\hline & $3-5$ & 71 & 35.1 \\
\hline & 6-8 & 59 & 29.4 \\
\hline & $>9$ & 42 & 21.0 \\
\hline & Total & 201 & 100 \\
\hline \multirow{5}{*}{ Age of respondents } & $18-25$ & 5 & 2.5 \\
\hline & $26-30$ & 3 & 1.5 \\
\hline & $31-35$ & 6 & 3.0 \\
\hline & $>36$ & 187 & 93.0 \\
\hline & Total & 201 & 100.0 \\
\hline \multirow{3}{*}{$\begin{array}{l}\text { Residential status } \\
\text { of respondents }\end{array}$} & Native & 147 & 73.1 \\
\hline & Migrant & 54 & 26.9 \\
\hline & Total & 201 & 100.0 \\
\hline \multirow{4}{*}{$\begin{array}{l}\text { Respondents } \\
\text { Educational background }\end{array}$} & Basic & 132 & 65.7 \\
\hline & Secondary & 16 & 8.0 \\
\hline & First degree & 53 & 26.4 \\
\hline & Total & 201 & 100.0 \\
\hline \multirow[t]{3}{*}{ Occupation of respondents } & Farmer & 197 & 98.0 \\
\hline & Mining activities & 4 & 2.0 \\
\hline & Total & 201 & 100.0 \\
\hline \multirow{6}{*}{$\begin{array}{l}\text { Years of experience } \\
\text { in the occupation }\end{array}$} & $1-5$ & 5 & 2.5 \\
\hline & $6-10$ & 7 & 3.5 \\
\hline & $11-15$ & 13 & 6.5 \\
\hline & $>16$ & 171 & 85.1 \\
\hline & Not sure & 5 & 2.5 \\
\hline & Total & 201 & 100.0 \\
\hline
\end{tabular}




\section{Macrothink}

\subsection{Data Collection}

\subsubsection{Household Data Collection and Analyses}

The main towns within the Asutifi North District include Kenyasi No.1 and Kenyasi No.2. The dominant occupation in these communities is farming. Data were collected from a total of 201 farming households on the farming systems, livelihood assets, importance of agriculture and mining and their perceptions of negative impact of these land uses. Farming households were chosen by randomly selecting houses from each community. Household heads were interviewed in each community to solicit a variety of information. The questionnaire responses received from the farming farmers were classified into items and each item's responses were tallied. The data were summarized using descriptive statistics (E.G. frequencies and percentages).

\section{Results}

\subsection{Common Agricultural Crops Produced within the Asutifi Area}

The respondents grow a variety of agricultural crops with the main crop being Cocoa for majority of them. The other crops are maize, yams, cassava, rice, plantain orange and oil palm (Table 2)

Table 2. Main agricultural crops and products

\begin{tabular}{|l|l|c|c|}
\hline Main Crop & Secondary Crop & Frequency & Percent \\
\hline Cocoa & & 173 & 86.1 \\
\hline Cocoa & Yam & 1 & 0.5 \\
\hline Cocoa & Rice & 4 & 2.0 \\
\hline Cocoa & Rice, maize & 2 & 1.0 \\
\hline Cocoa & Oranges & 6 & 3.0 \\
\hline Cocoa & Maize & 4 & 2.0 \\
\hline Cocoa & Oil Palm & 2 & 1.0 \\
\hline Cocoa & Cassava & 1 & 0.5 \\
\hline Cocoa, & Maize, plantain & 2 & 1.0 \\
\hline Cashew & & 3 & 1.5 \\
\hline Oil Palm & & 3 & 1.5 \\
\hline Total & & 201 & 100.0 \\
\hline
\end{tabular}

\subsection{Biophysical and Natural Assets of Farmers in Asutifi}

Respondents were asked to mention the biophysical and natural assets they owned. These assets were sub-categorized into productive and domestic assets. Table 3 shows the type of productive and domestic assets available to the communities. The majority (89\%) of the respondents listed cutlass as their main productive asset. This was followed by $9 \%$ of the respondents who claimed they have a cutlass and other productive assets such as a sprayer, motor, sickle, etc. for farming. The kind of domestic assets owned by respondents is presented in Table 3. 


\section{Mll Macrothink \\ Environmental Management and Sustainable Development \\ ISSN 2164-7682 \\ 2021, Vol. 10, No. 4}

Table 3. Biophysical and natural assets of survey respondents $(\mathrm{N}=201)$

\begin{tabular}{|l|l|l|l|}
\hline \multicolumn{2}{|l|}{$\begin{array}{l}\text { Indicators of biophysical and } \\
\text { natural assets }\end{array}$} & $\begin{array}{l}\text { Frequency of } \\
\text { responses }\end{array}$ & $\begin{array}{l}\text { Percentage } \\
\text { response }\end{array}$ \\
\hline $\begin{array}{l}\text { 1. Availability of productive } \\
\text { assets to respondents }\end{array}$ & Yes & 201 & 100.0 \\
\hline & No & 0.0 & 0.0 \\
\hline \multirow{3}{*}{$\begin{array}{l}\text { 2. Kind of productive assets } \\
\text { owned by respondents }\end{array}$} & 2 & 179 & 89.1 \\
\cline { 2 - 4 } & 1,2, & 4 & 2.0 \\
\cline { 2 - 4 } & 2,7 & 18 & 9.0 \\
\hline \multirow{4}{*}{ 3. Availability of domestic asset } & Yes & 192 & 95.5 \\
\cline { 2 - 4 } & No & 9 & 4.5 \\
\hline \multirow{4}{*}{$\begin{array}{l}\text { 4. Kind of domestic assets } \\
\text { owned by respondents }\end{array}$} & Nothing & 9 & 4.5 \\
\cline { 2 - 4 } & 1 & 15 & 7.5 \\
\cline { 2 - 4 } & 1,2 & 2 & 1.0 \\
\cline { 2 - 4 } & $1,2,3$ & 23 & 11.4 \\
\cline { 2 - 4 } & $1,2,3,5$ & 18 & 9.0 \\
\cline { 2 - 4 } & 1,3 & 26 & 13.0 \\
\cline { 2 - 4 } & 2 & 10 & 5.0 \\
\cline { 2 - 4 } & 2,3 & 58 & 28.9 \\
\cline { 2 - 4 } & $2,3,5$ & 16 & 10.0 \\
\cline { 2 - 4 } & 3 & 20 & 1.0 \\
\cline { 2 - 4 } & $3,6,5$ & 2 & \\
\cline { 2 - 3 } & 3,6 & 2 & 1.0 \\
\hline
\end{tabular}

Productive assets: hand hoes (1), cutlass (2), plough, (3), tractor, (4), car (5), irrigation equipment (6), other (sprayer, motor, sickle) (7)

Domestic assets: Radio (1), Television (2), Telephone (3), solar power $\quad$ (4), fridge (5) other/sewing machine, fan (6)

\subsection{Farmers Perception of the Impact of Mining on their Livelihoods}

When respondents were asked whether mining has contributed to increased household income, the majority ( $82 \%$ each) of them from both communities said "No" (Figure 2). The majority $(95.5 \%)$ of the respondents claimed that they were displaced as a result of mining operations in their communities. Only $4.5 \%$ were not displaced (Figure 4). All the respondents indicated that agricultural lands are increasingly being sold out and converted into mining concessions. For 44 farmers who gave accurate information, the majority had lost between 3 to 4 bags of cocoa yield due loss of land to mining operations (Table 4).

Respondents also reported several negative impacts of mining on them. Approximately, $62 \%$ of the respondents strongly agreed that mining has increased their living costs (Table 5). 24.4\% of the respondents said mining has contributed to school dropouts. Other negative impacts reported by the respondents included an increase in flooding and communicable diseases and destruction of farmlands and crops (Table 5). 


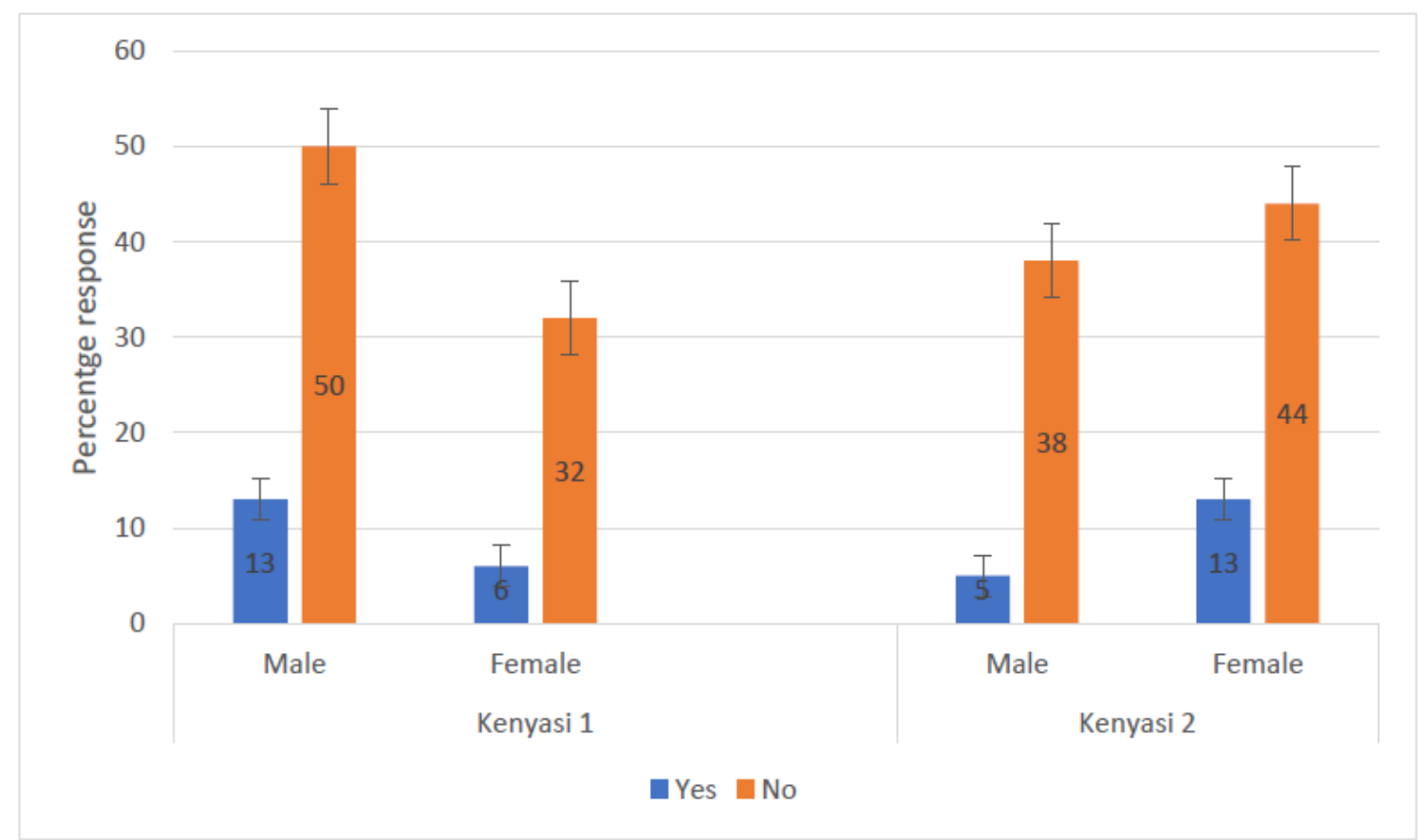

Figure 2. Respondents view on whether mining has contributed to increased household income. (Error Bar: 95\% CI)

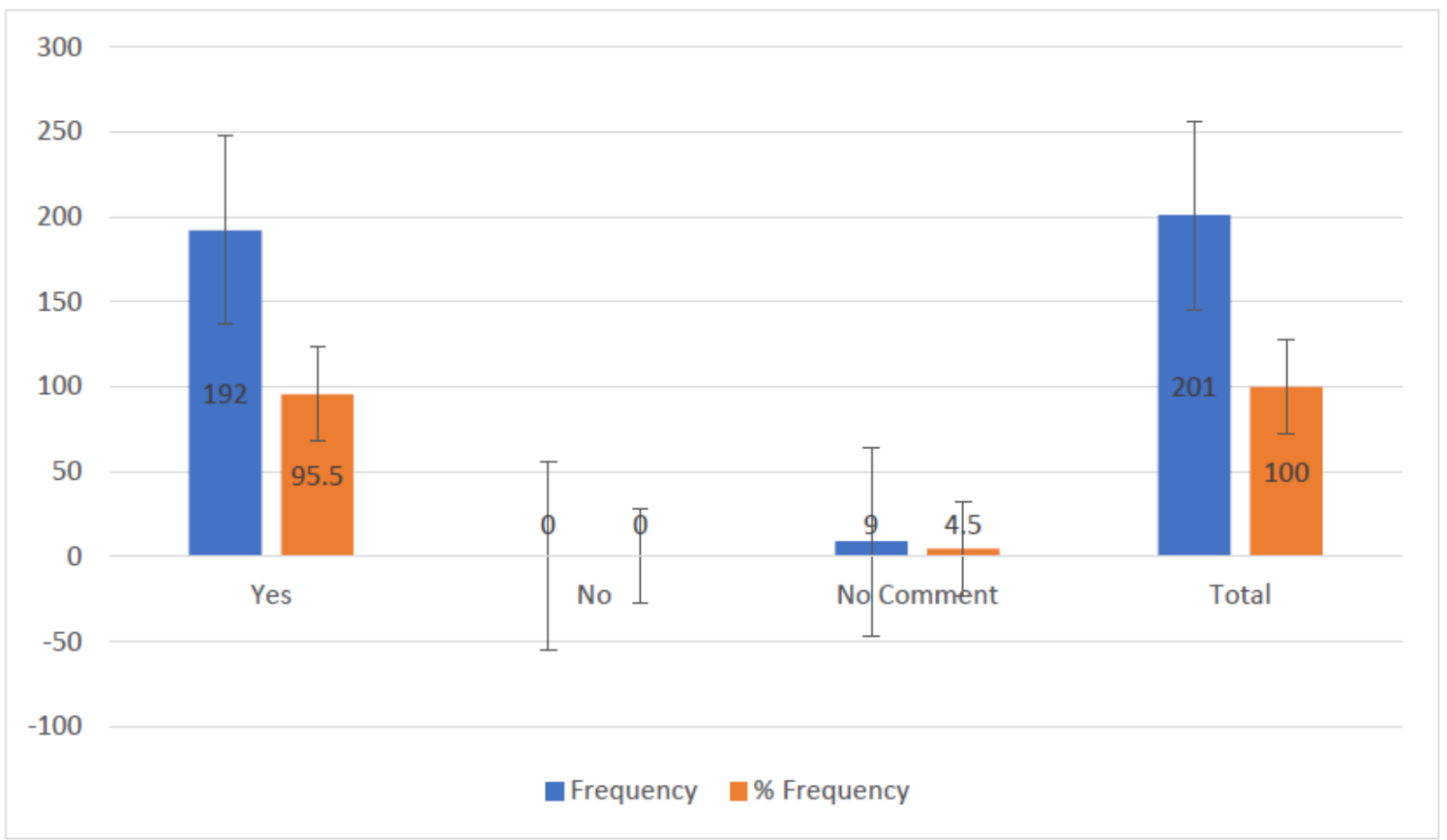

Figure 3. Average number of respondents displaced due to mining operations in both communities 


\section{Macrothink}

Environmental Management and Sustainable Development

ISSN 2164-7682

2021, Vol. 10, No. 4

Table 4. Farmers' estimated size of farmland lost to mining operations over the last 10 years $(\mathrm{N}=44)$

\begin{tabular}{|l|l|l|l|l|l|}
\hline Size (ha) & Frequency & Percentage & $\begin{array}{l}\text { Cocoa yield (bags) } \\
10 \text { years ago }\end{array}$ & $\begin{array}{l}\text { Cocoa yield } \\
\text { (bags) currently }\end{array}$ & $\begin{array}{l}\text { Cocoa yield loss (bags) } \\
\text { due to land degradation }\end{array}$ \\
\hline 1 & 1 & 2.3 & 7 & 5 & -2 \\
\hline 2 & 12 & 27.3 & 13 & 10 & -3 \\
\hline 3 & 10 & 22.7 & 20 & 14 & -6 \\
\hline 4 & 4 & 9.1 & 28 & 21 & -7 \\
\hline 5 & 3 & 6.8 & 32 & 27 & -5 \\
\hline 6 & 4 & 9.1 & 40 & 30 & -10 \\
\hline 7 & 3 & 6.8 & 49 & 40 & -9 \\
\hline 10 & 6 & 13.6 & 70 & 60 & -10 \\
\hline 90 & 1 & 2.3 & 630 & 600 & -30 \\
\hline $\mathrm{N}$ & 44 & 100.0 & & & \\
\hline
\end{tabular}

Table 5. Local people's perception on negative effects of mining on livelihoods

\begin{tabular}{|c|c|c|c|}
\hline Socio-economic variables & Level of agreement/Disagreement & Frequency & Percent \\
\hline \multirow{4}{*}{$\begin{array}{l}\text { Increased living cost } \\
(\mathrm{N}=201)\end{array}$} & 1 & 125 & 62.2 \\
\hline & 2 & 55 & 27.4 \\
\hline & 3 & 16 & 8 \\
\hline & 4 & 5 & 2.5 \\
\hline \multirow{5}{*}{$\begin{array}{l}\text { Increased school dropouts } \\
(\mathrm{N}=201)\end{array}$} & 1 & 20 & 10 \\
\hline & 2 & 29 & 14.4 \\
\hline & 3 & 65 & 32.3 \\
\hline & 4 & 82 & 40.8 \\
\hline & 5 & 5 & 2.5 \\
\hline \multirow{4}{*}{$\begin{array}{l}\text { Increase in social vices. } \\
(\mathrm{N}=201)\end{array}$} & 1 & 48 & 23.9 \\
\hline & 2 & 86 & 42.8 \\
\hline & 3 & 64 & 31.8 \\
\hline & 4 & 3 & 1.5 \\
\hline \multirow[t]{2}{*}{ Water pollution } & 1 & 90 & 44.8 \\
\hline & 2 & 111 & 55.2 \\
\hline \multirow{5}{*}{$\begin{array}{l}\text { Increased in water flooding } \\
\text { and diseases. } \\
(\mathrm{N}=201)\end{array}$} & 1 & 9 & 4.5 \\
\hline & 2 & 11 & 5.5 \\
\hline & 3 & 15 & 7.5 \\
\hline & 4 & 98 & 48.8 \\
\hline & 5 & 68 & 33.8 \\
\hline \multirow{5}{*}{$\begin{array}{l}\text { Degradation of farmlands and } \\
\text { destruction of crops }(N=201)\end{array}$} & 1 & 146 & 72.6 \\
\hline & 2 & 44 & 21.9 \\
\hline & 3 & 6 & 3 \\
\hline & 4 & 3 & 1.5 \\
\hline & 5 & 2 & 1 \\
\hline
\end{tabular}

Strongly Agree [1] Agree [2] Neutral [3] Disagree [4] Strongly Disagree [5] same [6] 


\section{Discussions}

\subsection{Livelihoods and Livelihood Assets of the Local People}

The results show that the majority of the respondents are cocoa farmers. As reported by Agariga et al. (2021) and presented in Table 1, 93\% of the farmers were above 36 years old indicating that cocoa farmers in the study area are in the working class with the mean age lower than the national population average which is 50 years (Lowe, 2017). The majority of the farmers had a household size ranging between 3 and 5. This is in agreement with the findings by many studiers (e,g. ICI 2017) reporting similar average household sizes for cocoa farmers in West Africa. The household size comprised mostly of the household head with his or her nuclear family and/or other relatives. About 93\% of the respondents had farmlands. The average farm size of the majority ranged from one to three hectares. These reported farm sizes are typical sizes of cocoa farms in rural West Africa (ICI, 2017). In addition to cocoa, the farmers grow other crops such as maize, yam, plantain, orange, cassava and oil palm.

In terms of assets, this study sheds light upon the basic assets of the farmers. The most important capital assets of the farmers were cutlasses and hoes. Important capital assets such as irrigation facilities and farm machinery were not available to most farmers. Irrigation is the life blood of farming and should be the first consideration. In terms of farm machinery, farmers are severely limited. Farmers have the most basic tools. Although the tools may be appropriate for the scale of farm production they engage in, machines such as tractors are often required for land preparation. But because having a tractor require high investment, the services of the tractors are often hired during the land preparation period without causing any inconveniences and loss of yield. It means that for many farmers, the opportunity cost of the limited capital is kept under consideration while seasonal hiring is resorted to.

An essential capital asset such as farm building were not mentioned as part of their assets. It was observed that farmers' livestock are kept on free range basis without protection from bad weather. Unfortunately, livestock that are kept in the open require extra energy to fight against rain, heat and cold which would necessitate extra feeding and care. The economics behind this is that if the provision of buildings costs more than the cost of feeding and care then it is uneconomical to build structures for the livestock. The building costs comprise the depreciation, interest on capital invested in building and its care and maintenance. The construction and cost of building depends on the nature of climatic conditions and the building material needed. The farmers' situation also means that there are no store rooms for protection of food-grains from deterioration by rodents, moisture, insect pests and pilferage. As for food and seed storage, farmers' livelihood assets have a significant impact on their livelihood risks and on their adoption of adaptation strategies. Farmers in these communities have the most basic livelihood assets in terms of social, financial and human assets as well as natural and physical assets. These assets may not be enough to mitigate their livelihood risks in agricultural production that relate to crop variety adjustment, water management, agricultural finance and agro-technical support. The results show that farmers do not have the means and capacity to deal with the risks in agricultural production associated with the threat of mining and the increasing threats of climate change. 


\subsection{Perception of Farmers on How Mining is Impacting their Well-being}

This study assessed the perception of farming households on the impact of mining on socioeconomic activities in the study area. The socioeconomic activities included living costs, education, social vices, health, and agriculture. Generally, farmers perceive mining to have negative impact on socioeconomic activities in their communities. Their living cost and agriculture are the most affected. The farmers had a strong agreement to the statement that mining has increased their living cost. They indicated that housing and high prices of domestic items are the most significant cost-of-living component. The introduction of mining into the study area has caused inflation leading to the cost of essential goods rising for the farming community. The salary paid to mine workers cause local merchants to raise their prices making life harder for farmers in the study area. A majority $(95.5 \%)$ of the respondents also reported that they were displaced as a result of mining operations in the communities. This opinion is supported by the finding by Boateng et al. (2014) that agricultural lands have been taken over by miners in mining communities in Ghana. Prajna, (2009) and Doso Jnr et al. (2015) noted that mining often displaces the rural community from their land and in some cases they lose their homes, agricultural lands, and forest-based livelihoods.

Also, the majority of farmers indicated that mining has degraded agricultural lands in the communities consequently reducing farm outputs; this agrees with the finding by Adjei et al. (2012) that mining has reduced agricultural outputs in Ghana. Some respondents disclosed that the number of bags of cocoa beans produced annually has declined significantly because of mining that destroyed part of their farming lands. The destruction of farmlands owing to mining is common in Ghana where mineral exploration activities have gained deep roots (Aryeetey et al., 2004). Similar findings by Owusu-Ansah and Smardon, (2015) highlighted that for four regions in Ghana which had previously contributed immensely to Ghana's food basket, present data shows that these regions (Western, Eastern, Ashanti and Brong Ahafo) recorded net food deficits owing to conversion of agricultural land to mining concessions. Loss of agriculture land to mining has greatly affected smallholder farmers in the Brong Ahafo region of Ghana (Owusu-Ansah, 2012).

Water pollution has often been reported as one of the negative impacts of mining (Macdonald et al., 2014). The finding by Kitula (2005) reported that pollution of water bodies with mercury is the most critical impact of mining in mining communities. In this study the farmers also make strong statements that mining has polluted their water sources that are needed for irrigation and domestic uses. Also, some farmers agreed that mining has had a negative impact on their health. Some of them reported an increase in diseases that are attributed to flooding and pits left unfilled by the miners. According to farmers, these areas become breeding grounds for mosquitoes and diseases. This perception agrees with the assertion by Hilson (2001) that mining activities leave stagnant water which serves as a breeding ground for mosquitoes (Kitula, 2005); Hilson, 2009).

The impact of mining on the security of community members was assessed and some farmers agreed that social vices such as robberies, stealing, drug abuse, prostitution etc. in the communities have increased and these are affecting their security. This result is in line with 
Kitula (2005), who reported that mining has increased robberies in mining areas due to the influx of migrants into mining areas in search of jobs. This opinion is supported by the finding by Dogbe (1995) that mining has increased drug abuse and prostitution in mining areas in Ghana. The farmers also agreed that mining has resulted in truancy in schools and increased school dropout by students. They attributed this to the fact that the students engage in mining activities to earn some income. They indicated that some of the students engage in mining activities for income to provide for their needs that their families are unable to provide. School dropout levels should be taken as a serious problem because, as Boateng (2017) reported, students who indulged in mining activities during school hours had poor academic performance. Some farmers, however, had a neutral view on the issue of school dropout as a consequence of mining.

\section{The Implications of the Study}

Both large and small-scale mining operation have resulted in environmental contamination including water pollution. Based on farmers' accounts, the pollution of water bodies poses a threat to the health and livelihood systems of the mining area's communities that depend on those water resources for domestic activities such as cooking. Despite the migration of agricultural labour to mining, for many of them the benefits from mining may not compensate for the loss of the livelihoods that existed when they engaged in agricultural production (Hilson, 2002; Kidido, et al., 2015;). The value of agriculture to these local people cannot be underestimated. In fact the mining areas regions (Western, Eastern, Ashanti and Brong Ahafo) (Aryeetey et al., 2004) contributed immensely to Ghana's food basket. But these regions have started recording net food deficits because of the conversion of agricultural land to mining concessions (Owusu-Ansah, 2012; Owusu-Ansah and Smardon, 2015). In addition to the food deficit, forest products and related essentials that the communities depend on are also lost. Forest products complement other sources of income and subsistence input (Beer, 1995; Dubois, 2003; World Bank 2008). A wide range of people in rural households in developing countries meets some part of their nutritional, storage, energy, agricultural, income, and medicinal needs from the forests (Arnold and Falconer, 1988; Beer, 1995). Income generated from forest products has been noted to account for the large share of rural household total income (Timko, et al, 2010; Mulenga, et al., 2014). Income generated from forest products is important in bridging seasonal or other cash flow gaps (Arnold, 2001). It also supports coping with specific expenses and to respond to other unusual opportunities. Leach and Fairhead, (1994) noted that income generated from forest products may be used for example to finance the hiring of labour, purchase of new seeds, and to generate initial capital for trading activities.

Mining is undermining all these livelihood systems and in these studies the following projected consequences can be made: The youths are likely to migrate from the communities to the cities a result of the displacement caused by mining. This affects the income levels of the local people since their main livelihood which is agriculture are destroyed. There will be increased grievances over scarce land resource that can lead to conflicts. Climate change can contribute to or intensify natural disasters, such as floods or droughts, which can compound existing land use problems introduce by mining and create complex crisis including food 
insecurity. It can be concluded that, farmers are being displaced, as a result of mining, agricultural lands are being degraded, water resources are losing their quality to be used for human consumption, agriculture, and other domestic purposes. The lack of these resources can have a tremendous effect on the social, economic, and political climate of a country and must be considered and addressed as some of the most immediate threats to Ghana national security.

\section{Acknowledgement}

We would like to thank the technicians of CSIR- Forestry Research Institute of Ghana for supporting in the data collection. We thank Fagg Murray for helping to proof read the article. The studies was self-financed.

\section{References}

Adjei, S., Oladejo, N., \& Adetunde, I. (2012). The impact and effect of illegal mining (galamsey) towards the socio-economic development of mining communities: A case study of Kenyasi in the Brong Ahafo region. International Journal of Modern Social Sciences, 1(1), 38-55.

Agariga, F., Abugre, S., \& Appiah, M. (2021). Spatio-temporal changes in land use and forest cover in the Asutifi North District of Ahafo Region of Ghana, (1986-2020). Environmental Challenges. https://doi.org/10.1016/j.envc.2021.100209

Akabzaa, T., \& Darimani, A. (2001). Impact of Mining Sector Investment in Ghana: A Study of the Tarkwa Mining Region, Washington DC, Structural Adjustment Participatory Review International Network (SAPRIN).

Amponsah-Tawiah, K., \& Dartey-Baah, K. (2011) Occupational Health and Safety: Key Issues and Concerns in Ghana. International Journal of Business and Social Science, 2, 119-126.

Arnold, J. E. M., \& Bird, P. (1999). Forests and the Poverty-Environment Nexus. UNDP/EC Expert Workshop on Poverty and the Environment, Brussels, Belgium.

Arnold, J. E. M., \& Falconer, J. (1988). Forests, trees and household food security. Social Forestry Network Paper 7a. London, Overseas Development Institute.

Arnold. J. E. M. (2001). Forests and People: 25 years of community Forestry. [Online] Available: http://www.fao.org/3/y2661e/y2661e00.pdf.

Aryee, B. N. A., Ntibery, B. K., \& Atorkui, E. (2003). Trends in the small-scale mining of precious minerals in Ghana: a perspective on its environmental impact. Journal of Cleaner Production, 11(2), 131-140. https://doi.org/10.1016/S0959-6526(02)00043-4

Aryee, B. N. (2001) Ghana's mining sector: its contribution to the national economy. Resources Policy, 27(2), 61-75. https://doi.org/10.1016/S0301-4207(00)00042-8

Aryeetey, E., Osei, B., \& Twerefou, D. K. (2004). Globalization, Employment, and Livelihoods in the Mining Sector of Ghana, 1980-2002. University of Ghana, Legon. 
Akram-Lodhi, A. H., \& Kay, C. (2009). Neoliberal globalization, the traits of rural accumulation and rural politics: the agrarian question in the 21st century. In Peasants and Globalization: Political Economy, Rural Transformation and the Agrarian Question, Routledge, London. p. 315-338.

Aubynn, E. A. (2003). Community perceptions of mining: An experience from Western Ghana (Master's thesis). University of Alberta, Alberta, Canada.

Ayensu-Ntim, A., Doso Jr, S., \& Twumasi-Ankrah, B. (2015). Effects of loss of agricultural land due to large-scale gold mining on agriculture in Ghana: the case of the Western Region. Br J Res [Internet], 2(6), 196-221.

Beer, D. (1995). Forests and rural livelihoods. [Online] Available:

http://www.fao.org/3/y2661e/y2661e04.pdf.

Boateng, A. (2017). Rethinking alternative livelihood projects for women of the pits: The case of Atiwa. Academic Journal of Interdisciplinary Studies, 6(2).

https://doi.org/10.1515/ajis-2017-0002

Boateng, O., Codjoe, F., \& Ofori, J. (2014). Impact of illegal small scale mining (galamsey) on cocoa production in Atiwa District of Ghana. International Journal of Advance Agriculture Research. 89-99. https://doi.org/10.1515/ajis-2017-0002

Chambers, R., \& Conway, G. (1992). Sustainable Rural Livelihoods: Practical Concepts for the 21st Century. IDS Discusion Paper 296, IDS, Brighton

Chuhan-Pole, P., Dabalen, A., Kotsadam, A., Sanoh, A., \& Tolonen, A. (2015). The Local Socioeconomic Effects of Gold Mining: Evidence from Ghana. World Bank, Washington, DC,USA. https://doi.org/10.1596/1813-9450-7250

Dogbe, M. (1995). The effect of sexually transmitted diseases (STDs). New Life Press. [Online] Available: https://www.ncbi.nlm.nih.gov/books/NBK11734/

Dubois, O. (2003). Forest-based poverty reduction: a brief review of facts, figures, challenges, and possible ways forward. In T. Oksanen, B. Pajari \& T. Tuomasjukka (Eds.), Forests in Poverty Reduction Strategies: Capturing the Potential (pp. 65-81).

Doso, Jnr, S., CIEEM, G., Ayensu-ntim, A., Twumasi-ankrah, B., \& Barimah, P. T. (2015). Effects of Loss of Agricultural Land Due to Large-Scale Gold Mining on Agriculture in Ghana: The Case of the Western Region. British Journal of Research, 2(6), 196-221.

Ellis F. (1999). Rural livelihood diversity in developing countries: evidence and policy implications. Natural Resources Perspectives, 40.

Garvin, T., McGee, T. K., SmoyerTomic, K. E., \& Aubynn, E. A. (2009) Community-company relations in gold mining in Ghana. Journal of Environmental Management, 90(1), 571-586. https://doi.org/10.1016/j.jenvman.2007.12.014

Habashi, F. (1996). Pollution problems in the mineral and metallurgical industries. Quebec: Metallurgie Extractive Quebec. 
Hall, J. B., \& Swaine, M. D. (1981). Distribution and ecology of vascular plants in a tropical rain forest: forest vegetation in Ghana. W. Junk Publishers, The Hague.

https://doi.org/10.1007/978-94-009-8650-3

Hilson, G. (2001). A contextual review of the Ghanaian small-scale mining industry. London: Imperial College Centre for Environmental Technology. [Online] Available:

https://pubs.iied.org/pdfs/G00722.pdf

Hilson, G. (2009). Are alternative livelihood projects alleviating poverty in mining communities? Experiences from Ghana. Journal of Development Studies, 45(2), 172-196. https://doi.org/10.1080/00220380802553057

Hilson, G. (2002). The Environmental Impact of Small-Scale Gold Mining in Ghana: Identifying Problems and Possible Solutions. Geographical Journal, 168(1), 57-72. https://doi.org/10.1111/1475-4959.00038

Hilson, G., \& Banchirigah, S. M. (2009). Are alternative livelihood projects alleviating poverty in mining communities? Experiences from Ghana. Journal of Development Studies, 45(2), 172-196. https://doi.org/10.1080/00220380802553057

International Cocoa Initiative (ICI). (2017). Cocoa farmers in Ghana experience poverty and economic vulnerability. [Online] Available:

https://cocoainitiative.org/news-media-post/cocoa-farmers-in-Ghanaexperience-poverty-andeconomic-vulnerability/

Ivanova, G., \& Rolfe, J. (2011). Assessing development options in mining communities using stated preference techniques. https://doi.org/10.1016/j.resourpol.2011.03.001

Kidido, J. K., Ayitey, J. Z., Kuusaana, E. D., \& Gavu, E. K. (2015). Who is the rightful recipient of mining compensation for land use deprivation in Ghana?. Resources Policy, 43, 19-27. https://doi.org/10.1016/j.resourpol.2014.10.004

Kitula, A. G. (2005). The environmental and socio-economic impacts of mining on local livelihoods in Tanzania: A case study of Geita District. Journal of Cleaner Production, 14(2006), 405-414. https://doi.org/10.1016/j.jclepro.2004.01.012

Kuntala, L-D., Kim, A. \& Chansouk, I. (2014). Informal mining in livelihood diversification Mineral dependence and rural communities in Lao PDR1. Southeast Asia Research, 22(1), 103-122. https://doi.org/10.5367/sear.2014.0194

Leach, M., \& Fairhead, J. (1994). The Forest Islands of Kissidougou: Social Dynamics of Environmental Change in West Africa's Forest-savanna Mosaic. Report to ESCOR, U.K. Overseas Development Administration, London.

Lowe, A. (2017). Creating opportunities for young people in Ghana's cocoa sector. Working Paper 511, Overseas Development Institute. [Online] Available:

https://www.odi.org/sites/odi.org.uk/files/resourcedocuments/11635.pdf

Mancini, L., \& Sala, S. (2018) Social Impact Assessment in the Mining Sector: Review and 


\section{Macrothink}

Comparison of Indicators Frameworks. Resources Policy, 57, 98-111.

https://doi.org/10.1016/j.resourpol.2018.02.002

Macdonald, F. K. F., Lund, M., Blanchette, M., \& Mccullough, C. (2014). Regulation of Artisanal Small Scale Gold Mining (ASGM) in Ghana and Indonesia as Currently Implemented Fails to Adequately Protect Aquatic Ecosystems. p. 401-405.

Mate, K. (1998). Boom in Ghana’s Golden Enclave. Africa Recovery, 11(3), 11.

Mulenga, B. P., Richardson, R. B., Tembo, G., \& Mapemba, L. (2014). Rural household participation in markets for non-timber forest products in Zambia. Environment and Development Economics, 19(4), 487-504. https://doi.org/10.1017/S1355770X13000569

Nyame, F. K., Grant, A. J., \& Yakovleva, N. (2009). Perspectives on migration patterns in Ghana's mining industry. Resources Policy, 34(2009), 6-11.

https://doi.org/10.1016/j.resourpol.2008.05.005

Obeng, E. A., Oduro, K. A., Obiri, B. D., Abukari, H., Guuroh, R. T., Djagbletey, G. D., \& Appiah, M. (2019). Impact of illegal mining activities on forest ecosystem services: local communities' attitudes and willingness to participate in restoration activities in Ghana. Heliyon, 5(10), e02617. https://doi.org/10.1016/j.heliyon.2019.e02617

Ocansey, I. T. (2013). Mining Impacts on Agricultural Lands And Food Security-- Case study of towns in and around Kyebi in the Eastern Region of Ghana. Turku University Of Applied Sciences.

Owusu-Ansah, F., \& Smardon, R. C. (2015). Mining and agriculture in Ghana: A contested terrain Mining and agriculture in Ghana: a contested terrain Fred Owusu-Ansah. Int. J. Environment and Sustainable Development, 14(4).

https://doi.org/10.1504/IJESD.2015.072087

Owusu-Ansah, F. (2012). Surface Mining and Perceived Risks: The Case of Three Farming Communities in the Brong-Ahafo Region, Ghana. LAP Lambert Academic Publishing AG \& Co KG, Germany.

Peprah, P. (2016). Assessing land cover change resulting from surface mining development (a case study of Prestea and its environs in the Western Region of Ghana) (Doctoral dissertation).

Prajna, P. M. (2009). Coal Mining and Rural Livelihoods : Case of the lb Valley Coalfield. Orissa, 44(44), 117-123.

Schueler, V., Kuemmerle, T., \& Schröder, H. (2011). Impacts of surface gold mining on land use systems in Western Ghana. Ambio, 40(5), 528-539.

https://doi.org/10.1007/s13280-011-0141-9

Timko, J. A., Waeber, P. O., \& Kozak, R. A. (2010). The socio-economic contribution of non-timber forest products to rural livelihoods in Sub-Saharan Africa: knowledge gaps and new directions. International forestry review, 12(3), 284-294. 
https://doi.org/10.1505/ifor.12.3.284

Walser, G. (2002). Economic impact of world mining (No. IAEA-CSP--10/P).

Wilson, S. A. (2019). Mining-induced displacement and resettlement: the case of rutile mining communities in Sierra Leone. Journal of Sustainable Mining, 18(2), 67-76. https://doi.org/10.1016/j.jsm.2019.03.001

World Bank. (2008). Forests sourcebook: practical guidance for sustaining forests in development cooperation. World Bank.

Yelpaala, K., \& Ali, S. H. (2005). Multiple scales of diamond mining in Akwatia, Ghana: addressing environmental and human development impact. Resources Policy, 30(3), 145-155. https://doi.org/10.1016/j.resourpol.2005.08.001

\section{Copyright Disclaimer}

Copyright for this article is retained by the author(s), with first publication rights granted to the journal.

This is an open-access article distributed under the terms and conditions of the Creative Commons Attribution license (http://creativecommons.org/licenses/by/4.0/). 